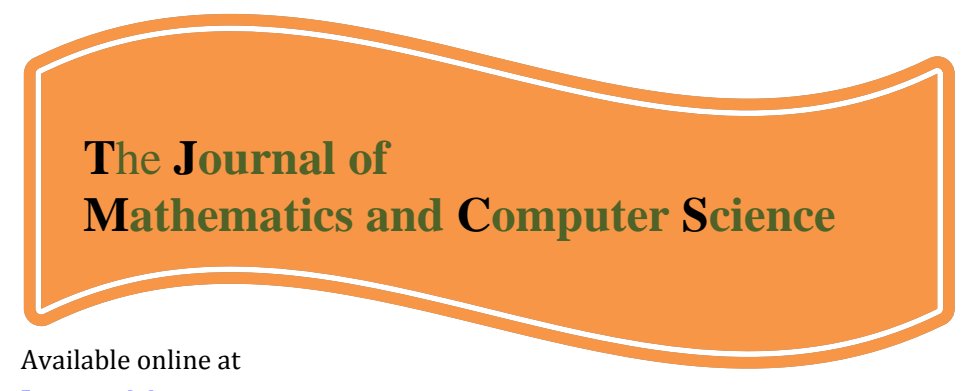

http://www.TIMCS.com

The Journal of Mathematics and Computer Science Vol .2 No.2 (2011) 359-375

\title{
Feasibility Study of Initiation of Electronic Commerce in Mazandaran Export Agencies by Using of AHP-FUZZY Technique
}

\author{
A. Sorayaei 1, ${ }^{*}$, S. M. Sajjadi Amiri, S. A. Sajjadi Amiri \\ Islamic Azad University, Babol Branch, Babol, Mazandaran, Iran \\ a.sorayaei@gmail.com
}

Received: September 2010, Revised: November 2010

Online Publication: January 2011

\begin{abstract}
The entrance of information and communication technology caused the evolution that named electronic commerce which is changing commerce methods, purchase and even our meditation. Even corporation that wants be successful in future, tries to execute a suitable strategy in electronic business.

In this article, we try to being familiar with electronic commerce and necessary foundation for executing electronic commerce, and then we investigate feasibility of e-commerce in Mazandaran Export Agencies under influencing these foundations and these effective factors will be ranked by using of fuzzy analysis hierarchy process technique. The results of this research show that technical foundation and organization foundation ranks are the same and they are first and then circumferential, commercial and financial foundations have the rank of second to forth and in properties ranking, with arrangement; the use of government support for information and e-commerce security, suitable organizational structure for directing the system, suitable planning for executing the e-commerce system, management support for executing the e-commerce system, skillful personnel, online transportation system and online discussing and requesting insurance; are the most important factors for executing the ecommerce system and they have gotten the most weigh in ranking.
\end{abstract}

Keywords: Feasibility, electronic commerce, Export Agencies, fuzzy analysis hierarchy process technique (AHP-FUZZY).

1 ,*-Corresponding author: Assistant Professor 


\section{1-Preface}

Nowadays Information Technology (IT) has a great effect on the business world. With the help of IT commercial and operating process are done during a few second instead of days or weeks \& this caused s better servicing to the customers in comparison to the past. Each company that is after achieving a success in the future tries to administer a suitable guideline in the field of electronic business .Electronic business has turns to an important subject in the world of business \& all organizations witch are after the improvement of efficiency \& outrunning the competitors are affected by this. Watter believes that electronic business is an essential part of the life. Just like a telephone is necessary in the business (Ebrahimi and Mahdie, 1385).

Electronic business describes the new models of avocations and includes the administration and coordination of the main processes of avocation along with the vast usage of computers, information technology, network technology \&computerizing the data. Acceptance of the electronic business, allows the small \&average computers to improve their commercial processes for the aim of buy and sale and internal activities (eBC.2005).Electronic business predisposed this context for avocation to pursue costumer-orienting guideline (strategy) and its needful relations meantime the specialization of the affairs and breaking down of the value continuum, in the form of accreting the exposition continuum. Therefore, based on this, electronic business was posed in the corporation's level and developed because of its excellent benefits (Fathi, 1383).

With the entrance of information technology \& communications in the arena of witch is changing the ways of business, buy and even our way of thinking. Electronic business made a basic change $\&$ alternation in the zone of competition $\&$ avocation by creating benefits such as improvement of efficiency, price reduction, and expense sowing and changing the size of the medium and accessibility of the exposures to the final consumers (Behkamal, 1384).

With approach of governments for the developing of the countries \& companies for partaking in the arena of international business, one of the most noteworthy method in the present time us the usage of information technology in the field of economic development witch indispensably in our country with the approach pf stable development of the government \&expansion of the industries for access to international markets \& using the commercial benefits of electronic business ,sporadic activities has been enforced in this case. In Iran public usage of internet is more I the universities \&for the aim of scholarship affairs and existing internet centers in the cities are limited and the usage of internet mostly includes internet talking \& telephoning. Also there is no required principles \& groundwork for electronic business in the country so we can't expect that the e-business spreads rapidly in the society.

The process of the administration of the commercial exchanges along with the development of science \& technology in the field of information transmittal in electronic method with the use of communal networks and its tools especially in the recent decades has confronted great alternations. Nowadays in some countries, electronic method of business has been accepted saliently. Based on the reports of existing sources, using electronic business abates a substantial percent of commercial expenses and has a remarkable effect on the prompting of the process of international \& international commercial competitions (Fazlali \& khosravani \& Farhani ,1386).

With regarding to the expansion of application of information technology \& communications in economy \&commerce in the international level \& its usage by the bargainers countries to Iran \&with regarding to its relative benefits, using these technologies under the name of electronic business \& electronic avocation is inevitable (memarnejad \& paryab, 1386).

In this condition and with the importance of membership of Iran in WTO, the entrance of e-business to Iran is an essential subject in the international business arena for exporting 
companies. But we should know that each organization that doesn't pay enough attention to e-business, will encounter the reduction of interest in a short time and the possibility of deletion of its existence in a long time (Tekye and etal, 1386). On the other side with regarding to EIU ranking for the year 2006 in the field of easiness and the rate of accessibility to e-business in 67 countries of the world, the position of Iran was reported to be the 64th.and this confirms that application of e-business in Iran is not in a suitable condition. Also it seems that the repellents \&problems related to the expert on the way of businessmen and exporting companies re the main gorge of guideline of exporting jump. Therefore, in order to get colder to this guideline its better to identify \& obviate these problems is in effective way e-avocation $\&$ e-business is one of the important tool which could change the zone of business and economy with a precipitous and revolutionary movement .Development of e-avocation \& ebusiness and its effect on competitive benefit of organizations and exporting countries, clarifies the role of this tool in obviation of exporting obstacles desirably (Fathi, 1383). Therefore to succeed in the electronic world and e-business the first and the most important step is planning for identifying the factors and criteria for his application of e-business (Azizi, 1384).

Sorayaei \& Mahdizadeh (1386) has studied the obstacles of the way of the electronic exchanges development in commercial corporations of Mazandaran province.The goal of this study has been the recognition of the obstacles and limitations of the applications of electronic exchanges in the commercial corporations of Mazandaran province and presentation of solutions for improvement and diminution or obviation of those obstacles. Therefore by the use of mooted models in this field the drafted model along with five factors of material, individual, technical, organizational and environmental obstacles we studied, the method of this study has been traversal descriptive and the aimed statistical group included of Mazandaran exporters in the year 1385.The results of this study shows that technical and environmental factors have been the obstacles of the application of e-business and individual. Organization and financial factors are not the obstacles .The ranking of e-business is respectively environmental. Technical, organizational, individual and financial criteria.

In the feasibility study of e-business in Iran, subtractions methodology .e-business subtractions were regarded and introduce them as perquisites for e-business in the country (Khajuei, 1383). These substructions include supportive institution, culture and people, technical readiness, economy and legal frame. This study: 1-reviews and indagates the first level of readiness.2-Extracts the results for development of researchers strategy for further studies grounding.3-Exposes the design and rudimentary results practically .Our frameworks are extended generally for electronic readiness and aim o provide tools for responding to various requests of different applications of e-business, to define variant ways of e-business and to clarify facilities in various economic fields.

In the story named designation of a e-vocation model for leading organizations, getting close to leading organizations was introduced as the way of achieving the constant competitive benefit and in the context of such kinds of organizations vocation model as studies and indicated. (Sepheri and etal), in this research, the organization vocation model has been known with three ambits of management of behaving to customer, developing the new products and management of substructions. And has been emphasized in the ambit of agreement of behaving to customer and apperception of market \& the codification circle of strategy if these kinds of organizations have been delineated.

Soheil sarmed saeedi (1382) has chosen the subject of "Indagation of environmental obstacles and presentation of a proper model for utilizing e-business" for his thesis. The method of this study was traversal but the comparative method and occasional studies were used too. The tool of data gathering was questionnaire .The statistic society of the study is constituted the internal companies and organizations and e-business experts among whom 120 persons or companies were selected accidentally .He has indagated the direct 
environmental factors (political legal, economic, social .cultural, technologic and population environment) and indirect environmental factors (merchants, competitors, customers, physical distribution units).

Kaynerk, Tatogluand Kula (2005) has indagated the effective factors on the trend of organizations in utilization of e-business in their study. In this study in which 237 companies in Turkey were indagated, the applicable programs of e-business, its benefits and limitations have been ranked .The applicable programs of e-business and their utilization ranking are respectively electronic post, searching and studying the WebPages of the companies, the study of product and market, exchanging the information with customers searching the information with suppliers, use of internet with other partners, receiving orders of customers, giving orders to suppliers, communication inside the company, electronic disburse of file transfer protocol, of e-business are categorized in for general groups naming the development of market, efficiency of sale \& elevation, ease of accessibility and abatement of expense \& 18 non-significant factors .In addition, he limitation of e-business in this study have been categorizes in 3 general groups of expense limitation, the limited number of users and security affairs.

By regarding to this matter that most of the studies in the field of e-business were on the different kinds of obstacles of e-business and indagation in the form of feasibility study of starting e-business has not been enforced generally in the country and restrictively in the provinces, therefore the researcher by consulting the experts, has decided to do some studies in the field of indagation and defining a set of required factors and substructions for starting e-business in exporting corporations of Mazandaran province and indagation if probability (feasibility) of starting e-business by adverting to the related substructions. According to the above-mentioned documentation, the exigency of doing researches related to e-business in the country generally and in the provinces (in this study Mazandaran province) restrictively for the aim of exploiting the benefits of advertising to it in the development of export, can favorably justify the current the study's designed affair. The aim of this study is first to recognize the effective factors in the according to the designed model in the table 1; by usage of AHP-FUZZY technique and to offer applicable suggestions.

\section{2-Tools and methods}

There are different methods for determining measurement tools authenticility (justifiability) and one of them is questioning the experts (Sorayaei \& Pakdin, 2008). The question measurement tools of the present study are authentic because he components of measurement criteria have been taken from the subjective literature of the study, in other words the experts agreed upon them. In addition the designed questionnaire, has been given to the experts and professors as pre-test \& then after gathering their amendatory opinions , the final questionnaire was designed for data gathering .As was told, the present today is a descriptive and traversal one.That is , at first the Delphi of opinion unit is specified from the experts by questionnaire of effective factors on the performance of the organization and then by using AHP-FUZZY method the ordering of effectiveness is determined. The statistic society of the present study includes the exporting experts of Mazandaran province who use the ebusiness facilities.

In the Delphi method, to decide on a special case, a group of experts are selected and their opinion are gathered thorough a questionnaire. Then he opinions are classified and are sent to whole members again, they check the opinions and handicap according to their own ideas. The researcher gathers and indagates them and chooses the most scored solution as the best decision. In this method there is no need that the members know each other and so the group pressure is reduced to the least amount (Alvani, 1379). 
Among the foursome tools for data gathering, the measurement tool for the present study was questionnaire. The method was that the questionnaire, in the first personal meeting, was given to the members of statistic society and the necessary explanations were given to them $\&$ in the second meeting the questionnaires were gathered.

After the gathering of needful data for the research, by the use of AHP-FUZZY method, the questions of the study were appraised. In this study the library method was used for the theoretical analysis \& the theoric segment of the work and points of view and attitudes of scholars along with the study of the books and articles \& documents and seminars. Since the study is descriptive, the gathering of information was alone by using questionnaires \& free tools.

\section{1-2- The process of hierarchal Analysis of fuzzy (AHP FUZZY)}

The method of hierarchical analysis I one of the most comprehensive designed system for decision making by using multiple criteria, because this technic provides the probability of formulating the affair hierarchically \& also is capable of regarding the various quantitative and qualitative criteria in the affair. This process applies various choices in decision making and is capable of analyzing the sensitivity on the criteria \& sub criteria. In addition, the base of duad comparison which facilitates the judgment and calculation is the excellent benefits of this technic in multiple criteria decision making (Asgharpour, 1383).

The Fuzzy prescription of the AHP technic encompasses the vague or not truly described situations. Different method of AHP-FUZZY, are the systematic approaches for selecting the choice by using the conception, the theory of FUZZY complexes and analysis of the hierarchical structure .In the year 1996 a method names Extent Analysis method (EA) was offered by a Chinese researcher named Chang. The numbers used in this method are triangular numbers ( Momeni, 1384) .

The present research was done in 2 steps .The aim of the first step was recognizing the obstacles \& important effective factors in establishment of the mentioned system among the factor achieved as the result of indagation and previewing the past researchers. In the second step by the use of AHP-FUZZY technique, the value of the criteria and selected choices (in the first step) were calculated and more important obstacles in the way of starting e-business were chosen.

\section{2-2-First step: Identification of criteria and affective factors in starting e-business:}

The most important affair in priority processing is the determine the choices correctly. In order to have a correct selection, determining criteria are needed. For achieving this goal, a large amount of researchers \& articles were studied. The result of these studies was the derivation of 5 criteria of priority processing \& 28 choices of feasibility factors for starting ebusiness. In the next step these 28 choices were indexed in a questionnaire to be distributed among experts. Then their arithmetic average was calculated for combination of charters. These choices (from A1 to A28) were indexes in the table No.1.

Table No, 1- tested choices of AHP-FUZZY

\begin{tabular}{|c|c|l|}
\hline Title & substructions & \multicolumn{1}{|c|}{ choices } \\
\hline \hline$A_{1}$ & $\begin{array}{c}\text { Financial } \\
\text { substruction }\end{array}$ & $\begin{array}{l}\text { Expense for teaching users and } \\
\text { leaders }\end{array}$ \\
\cline { 3 - 3 } & & Expense preparing of the \\
\hline
\end{tabular}


A. Sorayaei, S. M. Sajjadi Amiri, S. A. Sajjadi Amiri/ TJMCS Vol .2 No.2 (2011) 359-375

\begin{tabular}{|c|c|c|}
\hline & & network \& needed data base \\
\hline$A 3$ & & $\begin{array}{l}\text { Expense installation of e-business } \\
\text { system }\end{array}$ \\
\hline$A_{4}$ & & $\begin{array}{l}\text { Expense administration of e- } \\
\text { business system }\end{array}$ \\
\hline$A 5$ & & $\begin{array}{l}\text { Expense maintenance of e- } \\
\text { business system }\end{array}$ \\
\hline$A_{6}$ & \multirow{5}{*}{$\begin{array}{l}\text { Economic } \\
\text { \&banking } \\
\text { substruction }\end{array}$} & $\begin{array}{l}\text { Electronic transferring of } \\
\text { payments }\end{array}$ \\
\hline$A_{7}$ & & $\begin{array}{l}\text { Online request and negotiation } \\
\text { and contract of insurance back }\end{array}$ \\
\hline$A_{8}$ & & $\begin{array}{l}\text { Online monitoring of traffic } \\
\text { registration and custom } \\
\text { operation }\end{array}$ \\
\hline$A_{9}$ & & $\begin{array}{l}\text { Online transportation ordering } \\
\text { system }\end{array}$ \\
\hline$A_{10}$ & & $\begin{array}{l}\text { Online transferring of letters and } \\
\text { documents }\end{array}$ \\
\hline$A_{11}$ & \multirow{6}{*}{$\begin{array}{l}\text { Environmen-tal } \\
\text { substruction }\end{array}$} & $\begin{array}{l}\text { Using governmental supports foe } \\
\text { information and e-business } \\
\text { security }\end{array}$ \\
\hline$A_{12}$ & & $\begin{array}{l}\text { Internet communication of } \\
\text { personnels }\end{array}$ \\
\hline$A_{13}$ & & $\begin{array}{l}\text { International communication } \\
\text { with other organizations }\end{array}$ \\
\hline$A_{14}$ & & Public acquaintance of e-business \\
\hline$A_{15}$ & & $\begin{array}{l}\text { Creating fideism among people to } \\
\text { e-business }\end{array}$ \\
\hline$A_{16}$ & & $\begin{array}{l}\text { Public teaching to people in } \\
\text { various ways }\end{array}$ \\
\hline$A_{17}$ & \multirow{6}{*}{$\begin{array}{l}\text { Technologic-al } \\
\text { substruction }\end{array}$} & $\begin{array}{l}\text { Hardware facilities(computer, } \\
\text { modem, ...) }\end{array}$ \\
\hline$A_{18}$ & & $\begin{array}{l}\text { Software facilities (e-business } \\
\text { programs, ..) }\end{array}$ \\
\hline$A_{19}$ & & High speed internet \\
\hline$A_{20}$ & & $\begin{array}{l}\text { Enough band with for } \\
\text { downloading and uploading in in } \\
\text { internet }\end{array}$ \\
\hline$A_{21}$ & & Other transmission facilities \\
\hline$A_{22}$ & & Improving \& modernizing post \\
\hline
\end{tabular}


A. Sorayaei, S. M. Sajjadi Amiri, S. A. Sajjadi Amiri/ TJMCS Vol .2 No.2 (2011) 359-375

\begin{tabular}{|c|c|c|}
\hline & & via internet \\
\hline$A_{23}$ & & $\begin{array}{l}\text { Creating high penetration } \\
\text { coefficient via extending ISP }\end{array}$ \\
\hline$A_{24}$ & \multirow{5}{*}{$\begin{array}{l}\text { Organizatio-nal } \\
\text { substruction }\end{array}$} & $\begin{array}{l}\text { Proper organizational structure } \\
\text { for leading and controlling } \\
\text { working with EC }\end{array}$ \\
\hline$A_{25}$ & & $\begin{array}{l}\text { Proper planning for enforcing e- } \\
\text { business system }\end{array}$ \\
\hline$A_{26}$ & & $\begin{array}{l}\text { Management support for } \\
\text { enforcing e-business system }\end{array}$ \\
\hline$A_{27}$ & & $\begin{array}{l}\text { Efficient \& skilled personal, } \\
\text { aware of e-business }\end{array}$ \\
\hline$A_{28}$ & & $\begin{array}{l}\text { Proper interpersonal } \\
\text { communication }\end{array}$ \\
\hline
\end{tabular}

\section{3-2- second step: enforcement of AHP FUZZY method for ranking feasibility factors}

For assessment of the feasibility factors, assessment index must be defined and ranked. Since in this indagation, assessment is done buy using multiple and qualitative indexes and step by step, AHP (the process of hierarchical analysis) is a good method for this aim. Since most of the managers express their preferences \& ideas in lingual idioms instead of a numerical amounts, in priority processing of feasibility factors in starting e-business a AHP FUZZY frame was applied.

The selected method is for using AHP FUZZY technic, the method of extension analysis (EA) for valuating the indexes \&choices (Chang, 2001).

To overcome the uncertainly of affairs input parameters, decision making was done gregariously, that the ideas of experts \& the collection of their opinions was spotted as the final decision in each s special case (Kahraman , 2003).

A) Formation of hierarchial model: In this study, according to this method, first hierarchy of decision for ranking of feasibility factors for starting e-business is designed. To form the hierarchial model, we should first determine its three main level. The first level which is the highest level of hierarchial model is the aim of decision making that is ranking of the importance of feasibility factors of starting e-business the second level of hierarchial model after the aim, is criteria or criteria underlying the aim. In the present study, the criteria are financial, economic \& backing, environmental, technical \& organizational ones. The third level of hierarchial model, are choices. Choices are infact, the destination of the hierarchial model. (From A1 to A28). The graph No. 1 shows the structure of hierarchial model.

B) Designation of Matrix duad comparison: The aim of this step is to determine the values of criteria \& ranking of factors. Therefore business using the study hierarchial model (graph No, .1) the tables of duad comparisons are formed. In the first step the ideas \& preferences of experts about the importance of criteria \& choices are collected in the form of 
A. Sorayaei, S. M. Sajjadi Amiri, S. A. Sajjadi Amiri/ TJMCS Vol .2 No.2 (2011) 359-375

natural language words in the format of duad comparisons matrix \& then according to the conventional table of conversion in the EA method are converted to FUZZY numbers, then the FUZZY average of ideas is calculated \& finally the average of preferences in the form of triangular FUZZY numbers in the format of duad comparisons matrix is regulated.

Tabulate No.1-hierarchy of decision for ranking the feasibility factors of starting e-business 
First step: conversion of mental ideas of the experts to quantitative amounts: In this step the ideas of experts about the importance of choice to each other regarding to each criteria should be achieved .In such studied most of experts ideas are expressed in the format of natural language words and infact the grasp of experts ideas are mental. While these words can be regarded as lingual amounts and be described by FUZZY logic. Since in the method of Expansion Analysis, triangular Fuzzy numbers are used to show the amount of preferences, according to the below conventional table lingual variants (expert's preferences) are converted to triangular Fuzzy numbers:

Table No. 2- Conversion of lingual variants to triangular Fuzzy numbers

\begin{tabular}{|c|c|c|}
\hline Lingual variant & Triangular Fuzzy number & $\begin{array}{c}\text { The reverse of triangular fuzzy } \\
\text { number }\end{array}$ \\
\hline excellent & $(1,1,1)$ & $(1,1,1)$ \\
\hline The best & $\left(\frac{1}{2}, 1, \frac{3}{2}, 1,2\right)$ \\
\hline better & $\left(1, \frac{3}{2}, 2\right)$ & $\left(\frac{1}{2}, \frac{2}{3}, 1\right)$ \\
\hline average & $\left(\frac{3}{2}, 2, \frac{5}{2}\right)$ & $\left(\frac{2}{5}, \frac{1}{2}, \frac{2}{3}\right)$ \\
\hline little & $\left(2, \frac{5}{2}, 3\right)$ & $\left(\frac{1}{3}, \frac{2}{5}, \frac{1}{2}\right)$ \\
\hline very little & $\left(\frac{5}{2}, 3, \frac{7}{2}\right)$ & $\left(\frac{2}{7}, \frac{1}{3}, \frac{2}{5}\right)$ \\
\hline
\end{tabular}

Second step: consensus of expert's opinions: In order to determine the preferences in duad comparisons matrix, the consensus of a group of experts' opinions in the field of starting ebusiness was used. Since the analysis of complex affairs needs the opinions of several experts, in decision making by using the opinions of several experts their opinions are combined or adapted to achieve a unit decision.

Making decision by using the opinions of several experts is called afflux(consensus).Since the experts opinions are expressed in the form of natural language words and can be regarded as lingual amounts \& be described by Fuzzy logic, therefore the consensus of their opinions can be achieved through Fuzzy average.(Momeni ,1384).

As for making Fuzzy the importance of feasibility of starting e-business, triangular Fuzzy numbers were used, the consensus of experts opinions in this field, is calculated according to the below triangular average formula (the importance of opinions is assumed to be equal).

Assume $\mathrm{n}$ triangular numbers:

$$
\mathrm{A}_{\mathrm{i}}=\left(\mathrm{a}_{1}{ }^{(\mathrm{i})}, \mathrm{a}_{\mathrm{M}}{ }^{(\mathrm{i})}, \mathrm{a}_{r}{ }^{(\mathrm{i})}\right) \quad i=1, \ldots, n
$$


Usage of the pluralization of triangular numbers \& dividing it on a real number concludes to triangular average $A_{\text {ave }}$, the result is a triangular number that was shown in formula 1.

$$
\begin{aligned}
& A_{\text {ave }}=\frac{A_{1}+\ldots+A_{n}}{n}=\frac{\left(\sum_{i=1}^{n} a_{1}^{(i)}, \sum_{i=1}^{n} a_{M}^{(i)}, \sum_{i=1}^{n} a_{2}^{(i)}\right)}{n} \\
& A_{\text {ave }}=\left(m_{1}, m_{M}, m_{2}\right)=\left(\frac{1}{n} \sum_{i=1}^{n} a_{1}^{(i)}, \frac{1}{n} \sum_{i=1}^{n} a_{M}^{(i)}, \frac{1}{n} \sum_{i=1}^{n} a_{2}^{(i)}\right)
\end{aligned}
$$

Third step: The formation of duad comparison Matrix: In the next step with the help of acquired Fuzzy averages, duad comparisons matrix of criteria to each other and that of choices to each criteria is formed. In each of these matrix, each of the blocks upon the main diagonal shows the degree of importance of the row elements to column elements and each of the blocks under the main diagonal shows the degree of importance of the column elements to row elements and their value is reverse of the value of the blocks upon the diagonal. For instance the environmental, technical \& organizational) was shown in the table 3.

Table No. 3-Example of the present study duad comparison matrix substructions

\begin{tabular}{|c|c|c|c|c|c|}
\hline criteria & $C 1$ & $C 2$ & $C 3$ & $C 4$ & $C 5$ \\
\hline$C 1$ & $(1,1,1)$ & $(2 / 7,1 / 3,2 / 5)$ & $(2 / 7,1 / 3,2 / 5)$ & $(2 / 3,1,2)$ & $(1 / 2,2 / 3,1)$ \\
\hline$C 2$ & $(5 / 2,3,7 / 2)$ & $(1,1,1)$ & $(1 / 3,2 / 5,1 / 2)$ & $(1 / 2,2 / 3,1)$ & $(2 / 5,1 / 2,2 / 3)$ \\
\hline$C 3$ & $(5 / 2,3,7 / 2)$ & $(2,5 / 2,3)$ & $(1,1,1)$ & $(2 / 5,1 / 2,2 / 3)$ & $(1 / 3,2 / 5,1 / 2)$ \\
\hline$C 4$ & $(1 / 2,1,3 / 2)$ & $(1,3 / 2,2)$ & $(3 / 2,2,5 / 2)$ & $(1,1,1)$ & $(2,5 / 2,3)$ \\
\hline$C 5$ & $(1,3 / 2,2)$ & $(3 / 2,2,5 / 2)$ & $(2,5 / 2,3)$ & $(1 / 3,2 / 5,1 / 2)$ & $(1,1,1)$ \\
\hline
\end{tabular}

The data of the table No.3 was achieved by regarding to the average of the owners responded in the Likert spectrum of questionnaire and their Fuzzy average was defined, was converted to triangular Fuzzy numbers business using table No.2.

C) Calculation of the coefficients of duad comparisons matrices: After the formation of duad comparisons metrices and gathering data, it's turn to calculate the values of elements .For calculating the values, first the coefficients of each duad comparisons matrices and the amount of largeness of the elements to each other should be calculated, According to EA method, the coefficients of the matrixes are calculated based on the below formula. (Asgharpour, 1383)

$$
S_{K}=\sum_{j=1}^{n} M_{K L} \times\left[\sum_{j=1}^{m} \sum_{j=1}^{n} M_{i j}\right]^{-1}
$$


K shows the number of row \& i \& j are respectively choices \& criteria.

For example for the table of present study substructions the amount of duad comparisons matrix coefficients shown in the table No.3 are calculable according to following processes:

Table No. 4- Example of calculation of matrix coefficients for the present study matrix substructions(based on the formula)

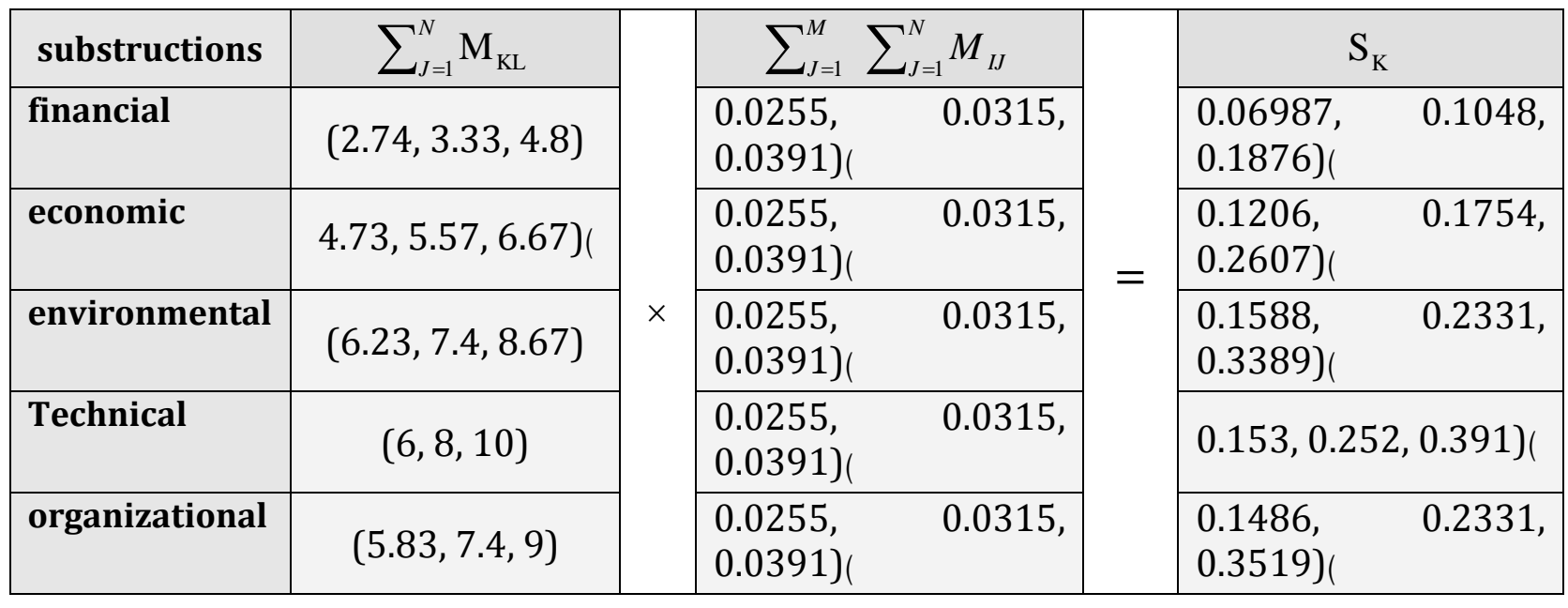

After calculation of $S_{K}$, we should calculate the degree of their largeness to each other. Generally if M1 \& M2 are two triangular Fuzzy numbers, the degree of largeness of M1 to M2 $\mathrm{V}\left(\mathrm{M}_{1} \geq \mathrm{M}_{2}\right)$, is described as below:

$$
\begin{array}{ll}
\mathrm{V}\left(\mathrm{M}_{1} \geq \mathrm{M}_{2}\right)=1 \quad \mathrm{~m}_{1} \geq \mathrm{m}_{2} & \\
\mathrm{~V}\left(\mathrm{M}_{1} \geq \mathrm{M}_{2}\right)=\operatorname{hgt}\left(\mathrm{M}_{1} \cap \mathrm{M}_{2}\right) & \text { Unless } \\
\operatorname{hgt}\left(\mathrm{M}_{1} \cap \mathrm{M}_{2}\right)=\frac{\mathrm{u}_{1}-\mathrm{l}_{2}}{\left(\mathrm{u}_{1}-\mathrm{l}_{2}\right)+\left(\mathrm{m}_{2}-\mathrm{m}_{1}\right)} &
\end{array}
$$

The amount of largeness of a triangular Fuzzy number from the $\mathrm{k}$ of another triangular Fuzzy number is also calculated from the following formula:

$$
\mathrm{V}\left(\mathrm{M}_{1} \geq \mathrm{M}_{2}, \ldots, \mathrm{M}_{\mathrm{K}}\right)=\mathrm{V}\left(\mathrm{M}_{1} \geq \mathrm{M}_{2}\right), \ldots, \mathrm{V}\left(\mathrm{M}_{1} \geq \mathrm{M}_{\mathrm{K}}\right)
$$

For example for the table of present study subtraction, the amount of largeness of triangular Fuzzy number of financial subtructions to each of economic, environmental technical \& organizational substructions are calculable as the table No.5 shows: 
Table No.5- the example of calculation of the amount of largeness of triangular Fuzzy number of financial substructions to other substructions(based on the formula 3

\begin{tabular}{|c|c|c|c|c|c|}
\hline largeness & & \multirow{5}{*}{$=$} & & \multirow{5}{*}{$=$} & \\
\hline $\begin{array}{l}\text { Financial criteria to } \\
\text { economical ones }\end{array}$ & $\mathrm{V}\left(\mathrm{S}_{1} \geq \mathrm{S}_{2}\right)$ & & $\frac{(0.187-0.120)}{(0.187-0.120)+(0.175-0.105)}$ & & 0.489 \\
\hline $\begin{array}{l}\text { Financial criteria } \\
\text { environmental one }\end{array}$ & $\mathrm{V}\left(\mathrm{S}_{1} \geq \mathrm{S}_{2}\right)$ & & $\frac{(0.187-0.158)}{(0.187-0.158)+(0.231-0.105)}$ & & 0.187 \\
\hline $\begin{array}{c}\text { Financial criteria } \\
\text { technical one }\end{array}$ & $\mathrm{V}\left(\mathrm{S}_{1} \geq \mathrm{S}_{2}\right)$ & & $\frac{(0.187-0.153)}{(0.187-0.153)+(0.252-0.105)}$ & & 0.187 \\
\hline $\begin{array}{c}\text { Financial criteria } \\
\text { organizational }\end{array}$ & $\mathrm{V}\left(\mathrm{S}_{1} \geq \mathrm{S}_{2}\right)$ & & $\frac{(0.187-0.148)}{(0.187-0.148)+(0.233-0.105)}$ & & 0.233 \\
\hline
\end{tabular}

Calculation of the above table is done exactly for each of the substructions to others and finally the least amount of largeness of each substructions to others was achieved in the form of table No.6 data.

Table No.6- example of calculation of the least amount of largeness (based on the formulas 4 \& 5)

\begin{tabular}{|c|c|c|c|}
\hline $\begin{array}{l}\text { Financial substructions to other } \\
\text { substructions }\end{array}$ & $\operatorname{Min} V\left(S_{1} \geq S_{2}, S_{3}, S_{4}, S_{5}\right)$ & \multirow{5}{*}{$=$} & 0.187 \\
\hline $\begin{array}{l}\text { Economic substructions to other } \\
\text { substructions }\end{array}$ & $\operatorname{Min} V\left(S_{2} \geq S_{1}, S_{3}, S_{4}, S_{5}\right)$ & & 0.581 \\
\hline $\begin{array}{l}\text { environmental substructions to other } \\
\text { substructions }\end{array}$ & $\operatorname{Min} V\left(S_{3} \geq S_{1}, S_{2}, S_{4}, S_{5}\right)$ & & 0.920 \\
\hline $\begin{array}{c}\text { Technical substructions to other } \\
\text { substructions }\end{array}$ & $\operatorname{Min} V\left(S_{4} \geq S_{1}, S_{2}, S_{3}, S_{5}\right)$ & & 1 \\
\hline $\begin{array}{l}\text { Organizational substructions to other } \\
\text { substructions }\end{array}$ & $\operatorname{Min} V\left(S_{5} \geq S_{1}, S_{2}, S_{3}, S_{4}\right)$ & & 1 \\
\hline
\end{tabular}

D) Calculation of criteria \& choices values: After calculation of degree of largeness, for calculating the value of elements, we do as the following in duad comparison matrix:

$$
\mathrm{W}^{\prime}\left(\mathrm{x}_{\mathrm{i}}\right)=\operatorname{Min}\left\{\mathrm{V}\left(\mathrm{S}_{\mathrm{i}} \geq \mathrm{S}_{\mathrm{k}}\right)\right\}, \quad \mathrm{K}=1,2, \ldots, \mathrm{n} \quad \mathrm{K} \neq \mathrm{i}
$$


For example, the vector of $\mathrm{W}^{\prime}\left(\mathrm{x}_{\mathrm{i}}\right)$ for our study substructions matrix will be:

$$
\mathrm{W}^{\prime}\left(\mathrm{x}_{\mathrm{i}}\right)=[0.187,0.581,0.920,1,1]
$$

The choices of the above expressions are extracted from table No.6 which calculated the least amount of largeness.

Therefore, the vector of elements will be:

$$
\mathrm{W}^{\prime}=\left[\mathrm{W}^{\prime}\left(\mathrm{c}_{1}\right), \mathrm{W}^{\prime}\left(\mathrm{c}_{2}\right), \ldots, \mathrm{W}^{\prime}\left(\mathrm{c}_{\mathrm{n}}\right)\right]^{\mathrm{T}}
$$

Then the vector of obnormal coefficients of AHP-FUZZY is converted to normal values according the following expression:

$$
w_{i}=\frac{w^{\prime} i}{\sum w^{\prime} i}
$$

Finally the sum of them is calculated $\left(\sum=3.688\right) \&$ from dividing each of the choices on the sum of them the amount of $W_{i}$ will be acquired as the following:

$$
w_{i}=[0.05,0.157,0.249,0.271,0.271]^{\mathrm{T}}
$$

The achieved numbers are the number of feasibility subtractions ranking in table No.7.

E) ranking of the importance of criteria \& choices: At the end, the results of calculation of the values of five criteria financial, economical \& backing, environmental, technical \&organizational (from c1 to c5) \& the result of calculation of 28 choices value related to ebusiness starting feasibility factors (from A1 to A28) are merged vie numeral average in order to achieve the comparative import.

Once coefficients of the choices .Table $7 \& 8$ shows the results of the above calculations in sequence of the importance of the factors (choices):

Table No.7-Ranking of e-business starting feasibility substructions

\begin{tabular}{|c|c|c|c|}
\hline row & Substructions & charter & priority \\
\hline \hline 1 & Financial & 0.050 & 4 \\
\hline 2 & Economic \&backing & 0.157 & 3 \\
\hline 3 & Environmental & 0.249 & 2 \\
\hline 4 & Technological \& technical & 0.271 & 1 \\
\hline 5 & organizational & 0.271 & 1 \\
\hline
\end{tabular}


A. Sorayaei, S. M. Sajjadi Amiri, S. A. Sajjadi Amiri/ TJMCS Vol .2 No.2 (2011) 359-375

The calculation of table 8 will be as such that for example for financial substructions , each number of financial substructions choices of primary value column is multiplied by the value of financial substructions from table No.7 that is the amount of $0.05 \&$ the result is the column of the primary value of the choices.This calculation was administered for the columns of final rank of organizational substructions choices.

Table No.8-Ranking of e-business starting feasibility choices based

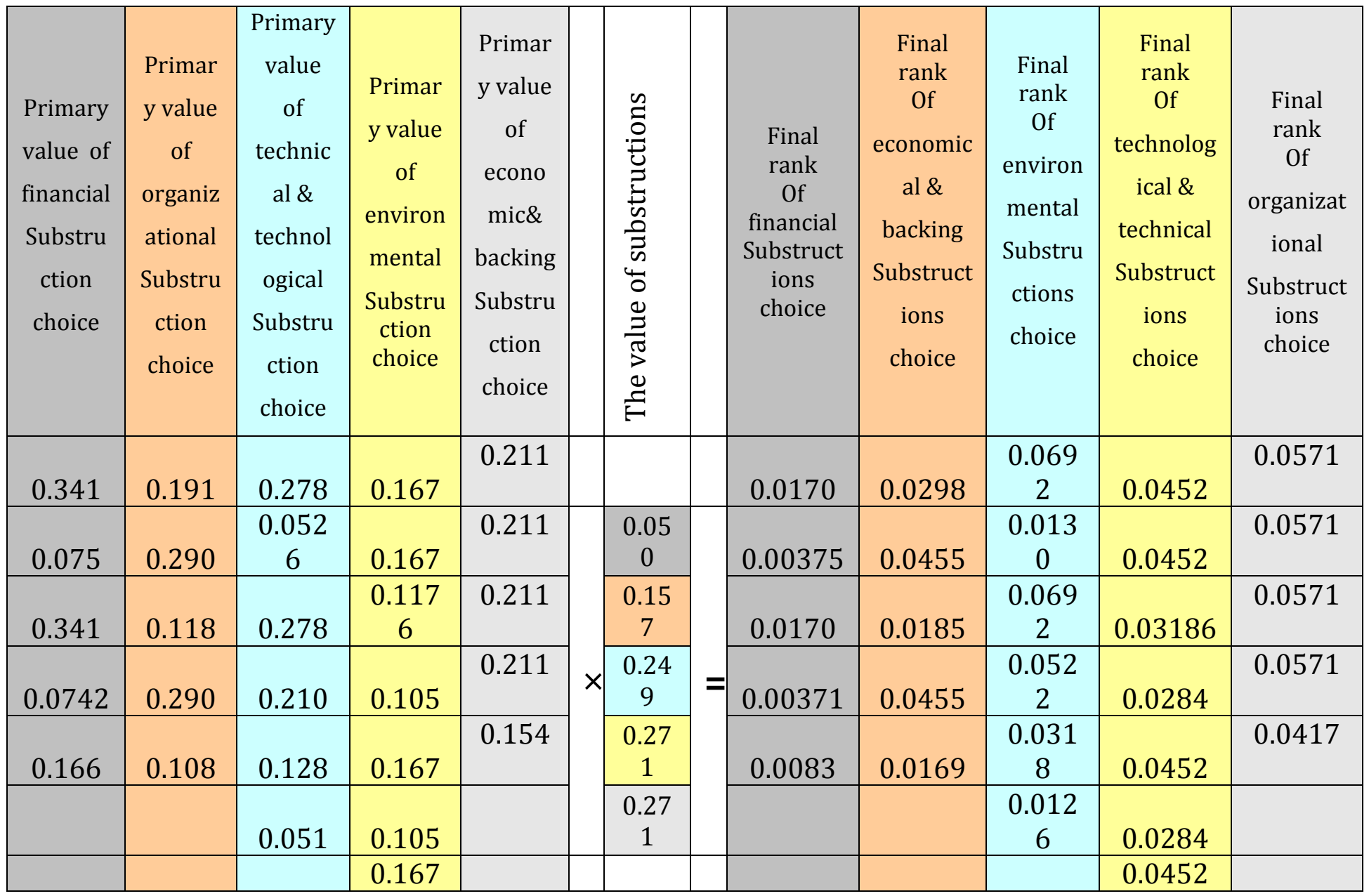

Finally in the table 9, the choices \& effective factors in feasibility of starting \& confirming e-business in exporting corporations of Mazandaran province with their charters \& ranks have been presented.

Table No.9-ranking of feasibility choices

\begin{tabular}{|c|c|c|c|c|c|c|c|}
\hline $\begin{array}{l}3 \\
0 \\
0\end{array}$ & choices & 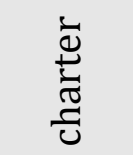 & $\begin{array}{l}\overrightarrow{2} \\
\stackrel{0}{0} \\
\stackrel{0}{a}\end{array}$ & $\begin{array}{l}3 \\
0 \\
0\end{array}$ & choices & 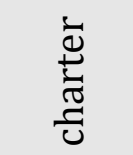 & 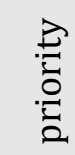 \\
\hline 1 & Expense for teaching users and & 0.0170 & 11 & 15 & Creating fideism among people to & 0.0318 & 8 \\
\hline
\end{tabular}


A. Sorayaei, S. M. Sajjadi Amiri, S. A. Sajjadi Amiri/ TJMCS Vol .2 No.2 (2011) 359-375

\begin{tabular}{|c|c|c|c|c|c|c|c|}
\hline & leaders & & & & e-business & & \\
\hline 2 & $\begin{array}{l}\text { Expense preparing of the network \& } \\
\text { needed data base }\end{array}$ & $\begin{array}{c}0.0037 \\
5\end{array}$ & 16 & 16 & $\begin{array}{l}\text { Public teaching to people in } \\
\text { various ways }\end{array}$ & 0.0126 & 14 \\
\hline 3 & $\begin{array}{l}\text { Expense installation of e-business } \\
\text { system }\end{array}$ & 0.0170 & 11 & 17 & $\begin{array}{l}\text { Hardware facilities(computer, } \\
\text { modem, ...) }\end{array}$ & 0.0452 & 4 \\
\hline 4 & $\begin{array}{l}\text { Expense administration of e- } \\
\text { business system }\end{array}$ & $\begin{array}{c}0.0037 \\
1\end{array}$ & 17 & 18 & $\begin{array}{l}\text { Software facilities (e-business } \\
\text { programs, ..) }\end{array}$ & 0.0452 & 4 \\
\hline 5 & $\begin{array}{l}\text { Expense maintenance of e-business } \\
\text { system }\end{array}$ & 0.0083 & 15 & 19 & High speed internet & $\begin{array}{c}0.0318 \\
6\end{array}$ & 7 \\
\hline 6 & Electronic transferring of payments & 0.0298 & 9 & 20 & $\begin{array}{l}\text { Enough band with for } \\
\text { downloading and uploading in in } \\
\text { internet }\end{array}$ & 0.0284 & 10 \\
\hline 7 & $\begin{array}{l}\text { Online request and negotiation and } \\
\text { contract of insurance back }\end{array}$ & 0.0455 & 3 & 21 & Other transmission facilities & 0.0452 & 4 \\
\hline 8 & $\begin{array}{l}\text { Online monitoring of traffic } \\
\text { registration and custom operation }\end{array}$ & 0.0185 & 10 & 22 & $\begin{array}{l}\text { Improving \& modernizing post } \\
\text { via internet }\end{array}$ & 0.0284 & 10 \\
\hline 9 & $\begin{array}{l}\text { Online transportation ordering } \\
\text { system }\end{array}$ & 0.0455 & 3 & 23 & $\begin{array}{l}\text { Creating high penetration } \\
\text { coefficient via extending ISP }\end{array}$ & 0.0452 & 4 \\
\hline $\begin{array}{l}1 \\
0\end{array}$ & $\begin{array}{l}\text { Online transferring of letters and } \\
\text { documents }\end{array}$ & 0.0169 & 12 & 24 & $\begin{array}{l}\text { Proper organizational structure } \\
\text { for leading and controlling } \\
\text { working with EC }\end{array}$ & 0.0571 & 2 \\
\hline $\begin{array}{l}1 \\
1\end{array}$ & $\begin{array}{l}\text { Using governmental supports foe } \\
\text { information and e-business security }\end{array}$ & 0.0692 & 1 & 25 & $\begin{array}{l}\text { Proper planning for enforcing e- } \\
\text { business system }\end{array}$ & 0.0571 & 2 \\
\hline $\begin{array}{l}1 \\
2\end{array}$ & $\begin{array}{l}\text { Internet communication of } \\
\text { personnels }\end{array}$ & 0.0130 & 13 & 26 & $\begin{array}{l}\text { Management support for } \\
\text { enforcing e-business system }\end{array}$ & 0.0571 & 2 \\
\hline $\begin{array}{l}1 \\
3\end{array}$ & $\begin{array}{l}\text { International communication with } \\
\text { other organizations }\end{array}$ & 0.0692 & 1 & 27 & $\begin{array}{l}\text { Efficient \& skilled personal, aware } \\
\text { of e-business }\end{array}$ & 0.0571 & 2 \\
\hline $\begin{array}{l}1 \\
4\end{array}$ & Public acquaintance of e-business & 0.0522 & 5 & 28 & $\begin{array}{l}\text { Proper interpersonal } \\
\text { communication }\end{array}$ & 0.0417 & 6 \\
\hline
\end{tabular}

Based on the result of No.9, using governmental supports for information \& e-business security, proper organizational substructions for leading \& controlling working with EC, proper planning for enforcing e-business system , management support for enforcement of ebusiness system, efficient \& skilled personnel, aware of e-business, online transportation ordering system, \& online request \& negotiation on a contract of insurance backing are ranked from the first to the third priorities and the choices of expense for maintenance of e-business system, expense for preparation if the network \& needed data base \& expense foe administration of e-business system are ranked from fifteenth to seventeenth priorities. 


\section{3-collection}

First step in confirmation of e-business in institutes \& corporation is to identify the factors and criteria for starting this system. Determination of the most important factors should be made by regarding to affective factors and criteria .In this study some factors for feasibility of starting e-business were identified and ranked that can be helpful for organizations in the decision making for confirmation of e-business system.

Managers need a step-by-step assessment method with the help of multiple criteria to successfully indagate the confirmation of e-business system, in order to prioritize the factors of confirmation of e-business system in their organization. Therefore in this study we used the AHP method (process of Hierarchical Analysis). Since most of managers express their preferences \& ideas in lingual idioms instead of numerical amounts, therefore in obstacles prioritizing, AHP-Fuzzy framework was applied. To use the AHP-Fuzzy techniqu, the method of extension Analysis (EA) to valuate the criteria \& choices was selected. This model includes 5 criteria and 28 choices.

\section{4-conclusion \& suggestions}

The result of this study showed that in ranking of criteria, respectively, technical substructions \& organizational substructions are in the first grade and then environmental, economic\& financial substructions are in the second to forth grades and in the prioritizing of the choices, respectively choices of using governmental supports for information \& ebusiness security, proper organizational structure for leading and controlling working with EC, proper planning for forcing e-business system , management support for enforcing ebusiness systems, skilled \& efficient personnel \& with enough information of e-business , online transportation ordering system and online request and negotiation \& contract of insurance backing are among the most important factors foe confirmation of e-business and have acquired more importance .

The most important suggestions of experts for confirmation of e-business system in exporting corporation of Mazandaran province are increase of governmental supports for information \& e-business security , criteria of a proper organizational structure for leading \& controlling working with EC, more effort for proper planning foe enforcing e-business system, growth of management supports for enforcing e-business system, using skilled \& efficient personnel with enough information of e-business for working at the organizations $\&$...

\section{5- Refrences}

[1] Ebrahimi, Abdolhamid; Mahdieh, Omid, Electronic Commerce, Tehran, Homay e Danesh Publication, 1385.

[2]Asgharpoor, Mohammadjavad, Multi criteria Decision Making, Tehran University Publication, 1383. [3]Alvani, Mehdi, Decision Making and Determining the government goal, SAMT Publication, 1379.

[4]Behkamal, Behshid; Razazi, Mohammadreza, Developing the UNCTAD model for determining the key factors of success of electronic commerce of an Institution, Papers of electronic commerce conference, Tehran University, 1384. 
A. Sorayaei, S. M. Sajjadi Amiri, S. A. Sajjadi Amiri/ TJMCS Vol .2 No.2 (2011) 359-375

[5] Tekye, Mehdi; Mahmoodzadeh, Soheil; Pariazar, Mahmood; Atbaee, Faramarz, Investigation of comparison of readiness of electronic commerce Using in organizations by using of AHP technique, Tehran, $2^{\text {nd }}$ International conference of electronic commerce and Global commerce, 1386.

[6]Sorayaei, Ali; Mehdizadeh, Ramezan, Investigation the preventing factors of electronic commerce exchanging on commercial Institution works in Mazandaran Province, Commercial Organization of Mazandaran Province research project, 1385.

[7]Khajoee, Moosa, The Study of electronic commerce feasibility in Iran: foundations Methodology, Tehran, $2^{\text {nd }}$ conference of electronic commerce, Assistant of Planning and Economic Research of Commercial Ministry, 1383.

[8]Sepehri, Mohammadmehdi,; Naserbakht, Narjes; Ferdosi, Zahra, The Planning of electronic business for guide organizations, Scientific Conference of Electronic Business and Electronic Commerce, Tehran University, 1384.

[9]Sarmad Saeedi, Soheil, Investigating the environmental preventing factors and offering suitable model for electronic commerce usage, Ph.D. thesis, Islamic Azad University, Oloom o Tahghighat Branch, 1382.

[10]Salmani, Behzad; Nasrollahzadeh, Shadi, Offered criteria for measuring the electronic commerce in Iran, Papers of $3^{\text {rd }}$ conference of electronic commerce, Tehran, Planning and Economic Ministry, 1384.

[11] Azizi, Shahriar; Khodadad Hosseini, Hamid; Elahi, Shaban. Identifying the preventing factors and the ways of using the electronic commerce; Iran Khodro Company, Commercial Bulletin, No. 37, 1384.

[12]Fathi, Saeed, Investigating the effect of electronic business on Iran improving the Industrial Exports, Tehran, Commercial Researches, No. 7, 1383.

[13] Fazali, Reza; Khosravani, Farahani, Findings of electronic commerce, Tehran, 2nd International conference of electronic commerce and Global commerce, 1386.

[14] Me'marnejad, Abbas, Paryab, Seyed Hossein, Investigating the readiness of Iran for electronic commerce usage, Tehran, $2^{\text {nd }}$ International conference of electronic commerce and Global commerce, 1386.

[15]Mo'meni, Mansoor, New discussions in Operation Research, Tehran University Publication, 1384.

[16]Chang,D-Y,Applications of the extent analysis method on fuzzy AHP.European journal of operational research,95,649-655.

[17]eBC - e Bsiness Connection, Critical Success Factors for e-Business, pp 1-5, derived from: http//:www.e-bc.ca, 2005.

[18]EIU, (2006), Economist Intelligence Unit: The E-Readiness Rankings, 2006. www.eiu.com.

[19]Kahraman, c.Ruan, D\& Doj, Fuzzy group decision making for facility location selection, information sciences, 157,2003.

[20]Kaynerk, E. \& Tatoglu, E. and Kula, V., An Analysis of the Factors Affecting the Adoption of Electronic-Commerce by SMEs: Evidence from an Emerging Market, International Marketing Review, Vol. 22, No.6, PP. 623-640, 2005.

[21]Sorayaei, Ali; Pakdin Amiri, Alireza. A Study of Manpower Productivity Status in Mazandaran (North of Iran) Province Payamnor University, The International Conference On Management Sciences and Arts, Gurukul Kangri university, Haridwar, Uttarakhand, India, 2008.

a.sorayaei@gmail.com

s_marzieh_sajjadi@yahoo.com

alisajjadi86@yahoo.com 